ant, first to the late Dr. Augustus Voelcker, and then to Prof. A. H. Church. In the next nine years Warington was chemist at Sir John Lawes's tartaric acid works, but in 1876 , being desirous of devoting himself entirely to research, he came again to the Rothamsted Laboratory, where he remained until I 890 .

Although Warington's chief interest was in agricultural chemistry, he published a number of papers dealing with inorganic chemistry, and a detailed account of the various salts of tartaric and citric acids as they occur in their natural sources and in the manufacture of these substances.

On his return to the Rothamsted Laboratory in I 876 , Warington introduced several improved methods of analysis to save time or ensure greater accuracy in the routine determinations; there also he carried out the investigations on nitrification by which he made his name. In 1877 appeared the paper of Schloesing and Müntz which showed that the production of nitrates in the soil must be due to living organisms; this work was repeated by Warington, who continued to investigate the conditions favourable to the process. He showed that light would inhibit the change, and that the drying of the soil was sufficient to destroy the organism; he also investigated the distribution of the organism, and showed that it was confined to the surface layers of ordinary soil, being only present in any quantity in the portion usually stirred by the plough. Observing that the oxidation of the ammonia or urea employed sometimes stopped at the stage of nitrite, he succeeded in demonstrating that the process in ordinary soils takes place in two stages due to different organisms, one oxidising ammonia to nitrous acid, the other completing the oxidation to nitric acid. Warington had actually accomplished the final step in the isolation of the two organisms, though he had not brought his work to the stage which satisfied himself, when his researches were unfortunately interrupted, and before he could resume Winogradsky published his elegant method of isolating the nitrous and nitric organisms by the use of a nutrient silica jelly.

The circumstances which led to Warington thus missing the credit of the crowning point of his long researches on nitrification undoubtedly caused him bitter disappointment; he continued to live in Harpenden, but took no further part in research. In the course of his investigations on nitrification Warington also observed and studied that other process of denitrification, by which previously formed nitrates are reduced again, often with loss of the nitrogen as gas. In later years this subject became very prominent for a time, but the essential conditions of the action had been laid down before in Warington's papers. He also investigated the method of estimating small quantities of nitrates by means of indigo, and devised a standard process which, in a simplified form, is now used by most water analysts.

Warington gave a course of lectures in America for the Lawes Agricultural Trust in $180 \mathrm{x}$; these were afterwards published by the United States Department of Agriculture; he was also Sibthorpian professor of rural economy at Oxford, $1894-7$.

His "Chemistry of the Farm" was published in $\mathrm{x} 88 \mathrm{r}$, and has since gone through fifteen editions; though only a small book, it is noteworthy for its lucidity and compactness in the handling of a mass of experimental data: it is a model text-book which has no rival in any language, and on it the present generation of agricultural chemists in this country has been educated.

Warington was elected to the Royal Society in r886; his connection with the Chemical Society, of which his father was one of the founders, dates back to 1863 ; he was vice-president from 1889 to 1893 , and in its Transactions appeared nearly all his original work.

Warington's scientific work is distinguished by clearness and precision; the range is not wide, but everywhere it shows the minute care and the regard for accuracy with which he worked; in these respects his work only reflected his personal character.

A. D. H.

\section{P. E. BERTHELOT.}

THE death of M. Berthelot was briefly recorded in the columns of Nature last week. The writer has been asked, as a former pupil of the great master, to give some account of his life and work.

Marcelin Pierre Eugène Berthelot was born in Paris on October 25,1827 . He was the son of a medical man, Dr. Jacques Martin Berthelot, and was educated at the Lycée Henri IV. In 1846 he obtained the prix d'honneur de philosophie at the concoursgénéral, open to the best students of the highest classes of the lycées of Paris. In February, $185 \mathrm{x}$, he became assistant (préparateur) to Balard, the discoverer of bromine, who held the chair of chemistry at the Collège de France. He kept this minor position until December, 1859 , when he was appointed professor of organic chemistry at the ficole superieure de Pharmacie. In 1865 a chair of organic chemistry was created for him at the Collège de France, which he held until his death. In $1870-1$ he acted as president of the Comité scientifique de défense during the siege of Paris. In 1873 he was elected member of the Academy of Sciences, of which he afterwards became perpetual secretary. In 1876 he was appointed inspector-general of higher education; in $188 \mathrm{r}$, senator for life. He was Minister of Public Instruction from December, 1886 , to May, I887, and Minister of Foreign Affairs in $1895-6$. In 1900 he was elected a member of the French Academy.

The French nation has from the time of the Revolution turned more than once to its scientific men for help in the conduct of national affairs. The names of Lavoisier, of Lazare Carnot, mathematician and organiser of victory, of Fourcroy, of Dumas, and of Paul Bert recur to the memory. But if Berthelot took an untiring part in public affairs, and especially, as member of the Conseil supérieur de l'Instruction publique, in educational affairs, it is not as an administrator or as a minister that he will be remembered, but as a chemist, and perhaps the greatest, as he was the most prolific, chemist of his age.

Of his first studies in chemistry I have found no account, but we know that Claude Bernard in 1848 asked him for chemical assistance in his early work on glycogen.

It was in 1850 that he published his first paper, on a method of liquefying gases. Between that date and $r 883$ the Royal Society's catalogue records against his name the titles of between 600 and 700 papers; it is probable that their total number falls little, if anything, short of a thousand, and to these must be added eighteen or twenty books, some of them, it is true, being only the summaries of published papers, but others, and especially his works on the history of chemistry, in a large measure independent publications. To estimate justly the value and influence of this colossal contribution to science would be the work of months rather than of a few hours, and, indeed, the very mass of the work has perhaps hidden something of its significance and of the importance of the underlying ideas.

Berthelot first gave his measure in his doctoral

Nก. 1952, VoL. 75 ] 
thesis on glycerin and the fats, published in 1854 . Chevreul had compared the fats to compound ethers, or esters, as we should now call them. Berthelot showed that the relation of glycerin to ordinary alcohol was comparable to that of phosphoric acid to nitric acid, thus introducing the important notion of polyatomic alcohols into chemistry. By a curious slip, inconsistent with the facts he had discovered, Berthelot compared the three series of glycerin esters to the orthophosphates, pyrophosphates, and metaphosphates, instead of to the neutral and "acid" salts of orthophosphoric acid. It was reserved to Wurtz, his great rival, to give the fullest interpretation and extension to his discovery.

The next question to which Berthelot devoted himself was a larger one. Gerhardt, who in the 'forties had contrasted the analyses of the chemist with the organic syntheses of nature, effected by the help of "vital force," already in 1853 , in the introduction to his "Traité de Chimie organique," described as the object of chemistry :--." la connaissance des moyens de composer tous les corps, la connaissance des moyens de décomposition n'en étant que le préliminaire obligé." But at that time the only organic compounds that had been synthesised from their elements were urea, by Wöhler, and acetic acid, by Kolbe. Berthelot set himself the great task of synthesising from their compounds the fundamental organic compounds, marsh-gas, formic acid, methyl and ethyl alcohol, acetylene, benzene-and succeeded. His work overthrew the "vital force" theory" as applied, not, indeed, to living matter, but to its non-living products. It forms the basis of those syntheses which have perhaps given to the chemistry of the nineteenth century its greatest prestige in the eyes of the world.

In his work on the fats, Berthelot had shown that they could be produced by the direct action of glycerin on the fatty acids, provided that time were given; it was characteristic of the man to generalise from this single discovery. In his work with his pupil, Péan de St. Gilles, on chemical affinity, published in $1862-3$, he first introduced into chemistry the study of rates of reaction and of reversible reactions. Few single researches in the history of chemistry have been more fruitful of results.

He next set himself a task comparable to the work on organic synthesis. C. L. Berthollet in the early years of the nineteenth century had written a famous treatise on chemical statics; it was Berthelot's ambition to lay the foundation of chemical mechanics as a whole by a systematic study of the heat-changes involved in chemical reactions. Andrews, Hess, Favre and Silbermann, and others had carried out isolated investigations in this domain, but Berthelot, and almost simultaneously Thomsen, the Danish chemist, set out to investigate the whole field of thermochemistry systematically. In his "Mécanique Chimique fondée sur la Thermochimie," published in 1879, Berthelot gives the result of fifteen years' assiduous work. Full of brilliant discoveries of detail, of ingenious methods of experiment and calculation, the work cannot be said to have realised to the full the ambitions of its author. The "principle of maximum work," which he regarded as his greatest generalisation, is incomplete. But his work is, nevertheless, monumental in extent, and forms the necessary starting point for all fresh researches on the subject. In 1897 he published a vast collection of thermochemical data under the title "Thermochimie, Données et Lois numériques."

In one branch of thermochemistry, that of explosions, Berthelot's discoveries are as novel as they are fundamental. Working mainly with his pupil Vieille, he found that when an explosive mixture or compound is fired, the flame proceeds through the mixture at a gradually increasing rate until a maximum rate is attained of which the value depends on the chemical composition of the explosive. This is the phenomenon of the " onde explosive," or explosion wave, especially familiar in this country through the remarkable work of Dixon, carried out subsequently. It was in the course of his work on explosive mixtures that Berthelot invented the well-known calorimetric bomb, an extremely simple and accurate instrument for determining the heats of combustion of organic compounds.

The problems of vegetable chemistry began to interest Berthelot in 1876 , when he showed that nitrogen could be made to combine directly with carbohydrates under the influence of the silent electric discharge. Later he found that the microbes of the soil played an important part in the fixation of nitrogen in the vegetable tissues-a discovery to which the work of Hellriegrel and Wilfarth on leguminous plants gave the most brilliant confirmation.

In I884 a fine laboratory was built for him on the heights of Meudon, and here, with the devoted and able collaboration of M. G. André, he carried out the vast series of researches on vegetable chemistry recorded in the four volumes on "La Chimie végétale et agricole,"' published in 1899 .

Berthelot's work in the history of chemistry is on the same kind of scale as his experimental work. In a first book, "Les Origines de 1'Alchimie," he traces alchemy to its origin in a combination of the ideas of Egyptian metal-workers (who from the practice of making alloys naturally desired to economise the use of the precious metals in their production) and of the Greek ideas of the transmutation of elements current in the school of Alexandria. In $1887-8$ he published a more comprehensive work, in collaboration with C. E. Ruelle, the "Collection des Alchimistes grecs." This was followed in 1893 by a similar work, "La Chimie au Moyen-âge," which deals with the Syriac and Arabic alchemists, translated by MM. Rubens Duval and Houdas. The author showed that the Latin works previously attributed to Geber (or Djaber, as he should be called) were late forgeries, and published authentic texts of the famous alchemist. These he supplemented in his last work, "Archéologie et Histoire des Sciences" (published in 1906), by printing the Latin translation of another work of Geber, the "Liber de Septuaginta," of which the Arabic original has been lost, together with a number of fresh memoirs on mediæval chemistry and on the composition of metallic specimens of Egyptian, Chaldaic, Persian, and Roman origin. On the more modern history of chemistry he published a book on Lavoisier, "La Révolution chimique" ( 1890 ), containing extracts from Lavoisier's note-books, and "La Synthèse chimique" (I875).

Besides these works and practical treatises on calorimetry and gas analysis, he published a number of volumes of essays-- "Science et Philosophie" (r886), "Science et Morale" (1897), "Science et Éducation " (I901), "Science et Libre-Pensée" (second edition, 1905); and the correspondence with Ernest Renan, who in his "Souvenirs d'Enfance" has left so interesting an account of the beginnings of the life-long friendship of the two men, was issued in 1898 .

The "Cinquentenaire scientifique de M. Berthelot" gives an account of the jubilee celebration held at the Sorbonne on November 24, I90I, when, in the presence of the President of the French Republic and the great officials of State and of the learned bodies of France, M. Berthelot received the congratulations of the academies of the world. "Dès que vous abordez une question," said Moissan in addressing him on

NO. I 952, VOL. 75$]$ 
behalf of the French Academy of Sciences, "vous l'étendez en la généralisant." But few men have united with the power to generalise such marvellous quickness and tenacity in workiis out detail. That quickness and tenacity may be estimated by the volume of his work. In his later life he had, of course, much help, but in his earlier years, when he often passed the night in the laboratory, he worked single-handed. Berthelot rejected until well into the nineties (as Bunsen did until his death) the use of the atomic notation, chiefly perhaps from a horror of the enthusiastic and somewhat uncritical faith of contemporaneous exponents of the atomic theory.

In person Berthelot was short and slight, and with the stoop of the student. In lecturing he spoke rapidly and in a low voice, with no attempt at oratorical effect. But his fine, regular features and brilliant blue eyes left an impression not easily to be forgotten. Reserved and almost cold in manner, he cared for two things supremely, his work and his family. He survived the shock of his wife's death, which took place on March I8, only by a few minutes.

The French Parliament voted a public funeral; it took place on Monday in the Pantheon, where the remains of his wife rest beside his own.

M. Berthelot left a daughter and four sons, of whom one, M. Daniel Berthelot, is well known for his researches in physical chemistry, and occupies a chair at the Ecole supérieure de pharmacie.

\section{P. J. HARTOG.}

\section{NOTES.}

MEN of science in this country will probably have to wait a long time before they will see the Government and the nation pay such a tribute to the greatness of one of their number as was witnessed in Paris on Monday, when the national funeral of $\mathrm{M}$. and $\mathrm{Mme}$. Berthelot took place at the Panthéon. Here politicians and people have little sympathy with intellectual greatness; and if $\mathrm{M}$. Berthelot had lived in Great Britain instead of France his death would have been mourned by the world of science, but the Government would certainly not have hastened to secure for him the honour of a national funeral, because our statesmen do not know the influence of scientific work on national character and progress; and to them men of science live in a world, far beyond the range of practical politics, where virtue finds its own reward. To understand the right spirit of appreciation of a great man of science we have to cross the Channel, and be present at a funeral like that of M. and Mme. Berthelot; for on such an occasion the French manifest incomparable qualities of organisation and tact. From the report of the Paris correspondent of the Times we learn that not since the funeral of Ernest Renan have the population of the capital been invited to join the authorities in such a solemn demonstration of mourning for one of their great compatriots. Amid impressive surroundings all that is representative of the dignity of the State was assembled, from the President of the Republic to the members of the several academies, the council of the Legion of Honour, the Ministers, the members of Parliament, and a host of the most eminent personalities of France. After a portion of Beethoven's Symphony in $\mathrm{C}$ minor had been rendered, the Minister of Education, M. Briand, ascended a small platform erected near the academicians and read a funeral oration in which he worthily honoured the illustrious dead. Berthelot's attitude towards the religious sentiment he accurately summarised in the terms of a formula borrowed from

$$
\text { No. 1952, VOL. } 7.5 \text { ] }
$$

Renan-" The real way of adoring God is to know and love what exists." Respecting Berthelot as a savant, he dwelt particularly on his roble as a creator, the forerunner of more startling syntheses still. The great moral quality of the man, the natural consequence of his philosophical ideas, was tolerance. After the oration, the two coffins were carried to the peristyle of the Panthéon, where a monumental catafalque had been raised. A splendid military pasgeant followed, the troops defiling past the coffins to the strains of the "Chant du Départ" and "Les Girondins," while flags were lowered and swords raised in salutation of the dcad. In the afternoon the public was allowed to visit the Panthéon, and in the evening the bodies were taken to the Panthéon vaults, where they occupy provisionally a place next to the remains of Victor Hugo.

ScIExtific men will do well to watch the course of events connected with the subject of Mr. Haffkine's prophylactic and the Mulkowal accident, referred to by Prof. Ross in last week's NATURE, as it is important that laboratories engaged in making prophylactics and sera shall not be lightly discredited on inadequate evidence-important not only for the laboratories, but for the public, which in its alarm is led to reject these valuable agents. In the House of Commons on March 20, Mr. Morley gave a cautious written reply to a question by Sir W. Collins on the subject. He stated that Mr. Haffkine is still in the employment of the Government of India, and has been offered "employment in that country on research work at a salary equal to that of which he was in receipt when he left India." But it is understood that Mr. Haffkine is holding out, not for the loaves and fishes of office, but for the vindication of himself, his laboratory, and his science from what appears to have been at least a very doubtful verdict. Mr. Morley also stated, somewhat too cautiously, that "Dr. Haffkine's prophylactic continues to be one of the precautions which are recommended by Government to the general populations against outbreaks of plague." But this is quite an inadequate description of it. Mr. Morley appears to have overloolsed the facts that in official statements other measures, such as segregation, disinfection, and evacuation, have been declared to be unavailing; that in the epidemic now raging in the United Province of Agra and Oudh, the Government of the province reported only last month (Bombay Gazette, February 18) to the effect that the prophylactic was the only measure affording real and substantial protection; and that in the Punjab alone, up to October, 1903, 1,327,075 people had been inoculated, with a declared reduction of mortality to about one-twelfth that occurring in the uninoculated (report on plague and inoculation in the Punjab by the chief plague medical officer, Lahore, 1904). But Mr. Morley may be trusted to see that justice (and, let us hope, something more) is done in this case.

LoRD Kelvin, O.M., has been nominated as presidentelect of the Institution of Electrical Engineers for the session rao $;-8$, his term of office as president to begin next November. Prof. J. J. Thomson has been elected an honorary member of the institution.

Lord Avebury will preside at the annual soiree of the Selborne Society, which will be held at the Civil Service Commission (Old London University), Burlington Gardens, on Friday, April 26. Illustrated addresses will be given, and there will be a display of microscopes and objects of interest.

A Times correspondent at Kingston, Jamaica, reports that earthquake shocks are recurring with alarming frequency, the latest being at $1.3^{0}$ a.m. on March 25. All 